\title{
Food rules in the Koran
}

\author{
Tahire O. Kocturk
}

The International Centre for Research on Migration, Medicine and Psychiatry, Huddinge, Sweden

\section{Abstract}

Islam is now the second largest religion in Scandinavia and has a high representation among immigrant groups. Knowledge of food rules in Islam is a necessity for nutritionists in multicultural settings. Food rules as they appear in the Koran are contained within the concepts of halal and haram. Halal means lawful, permitted and recommended by the Islamic law. Haram is the opposite, meaning unlawful, prohibited. Food rules are meant to be observed by postpubertal people in good physical and mental health living under peaceful social and economic conditions. This article clarifies the Koranic verses and traditions regulating food consumption.

Keywords: Food rules, immigrants, Islam, Koran, Old Testament.

\section{Islam: a background}

Let man reflect on the food he eats...

(The Koran, 80:18-33)

Islam is a religion that builds upon the JudeoChristian tradition. It is a majority religion in areas including the Near and Middle East, the Caucasus, central Asia, north and east Africa, the Arabian peninsula, Indonesia and Malaysia, and is represented among many minority groups in Europe, the Americas, Russia, China and Australia. Islam is estimated to be the second largest faith after Christianity world-wide.

The Muslim calendar begins in the year AD 622. However, the events leading to the birth of this monotheistic religion occurred some 12 years earlier, around $\mathrm{AD}$ 610, during the lunar month of Ramadan, when the Prophet Muhammed (AD 570-632) received the first revelation affirming the oneness of God from archangel Gabriel (see Surah 96), at mount Hira near the city of Mecca on the Arabian Peninsula. The word "islam" means total submission and refers to the basic teaching of absolute submission to the will of God. God is the one and only, omnipotent, allknowing and merciful creator of the entire universe. Muhammed is considered the last of God's messengers after Adam, Abraham, Moses and Jesus, to whom the will of God has been revealed as collected in the Old Testament and in the Koran. The word Koran means reading or recitation and contains the revelations that Muhammed received during his lifetime. The revelations were originally committed to memory or written on whatever material was at hand at the time they transpired. These were later collected in the Koran and organized in order of length rather than chronologically, during the reign of the caliph Osman (AD 644-656). Islam maintains that the Koran is the infallible word of God to which all practising Muslims must submit.

Islam has a number of denominations, primarily Sunni, Shia and Sufi. Sunni is the largest, encompassing around $90 \%$ of all Muslims. It is faithful to the customs of the original Islamic state and the examples (sunna) established by the Prophet Muhammed. All of the denominations in turn differ in their interpretation and application of religious law. (The Sunni tradition, for instance, has four schools of religious law.) These religious laws, or Sharia, are still in force in some Muslim countries, while in others, they have been replaced by secular law. Food rules are very similar among the Sunni and Shia and most of the Sufi, ${ }^{*}$ regardless of the type of law applied in their country of residence. Practising Sunnis and Shi'ites living in secularized countries are also likely to make an effort to follow the food rules of the Koran.

\footnotetext{
* Exceptions may be made in the prohibition against wine and alcohol, and fasting procedures may vary among some Sufi denominations.
} 
Food rules are contained within the concepts of halal and haram. Halal means lawful, permitted and recommended by the sheria. Haram is the opposite, meaning unlawful, prohibited. Between these two extremes lies the concept of mushbooh, which means doubtful or suspect. It proscribes the utilization of any food or practice as long as its halal status according to the Koran and the tradition (sunna) is unclear.

Like many other aspects of everyday life in Islam, food rules are meant to be observed by postpubertal people in good physical and mental health living under peaceful social and economic conditions. Children, disabled people not completely in control of their physical or mental capacities and people going through a difficult time in their lives (hard physical work, war, travelling, latter months of pregnancy, nursing and menstruation) can be exempted from the rules $(2: 173,6: 45,16: 114-18)$. The explanation is that "God desires your well-being, not your discomfort" (2:185). Food in general is described as a "sign" from God for which believers owe gratitude (e.g. 2:170). Food is referred to as "wholesome things". The recommendation to "eat of all wholesome things which are lawful to you" is a recurring sentence in several Surahs (e.g. 2:170, $5: 5,20: 81)$. Food is a blessing to be enjoyed and shared (24:61). Foods specifically mentioned in the Koran include honey, dates, milk, semolina, game and wine. Halal rules occur mostly in the Surahs entitled The Cow (2), The Table (5) and Cattle (6).

\section{Halal rules}

All vegetables, fruits and sea products are halal (5:96).

\section{Breast-feeding is halal}

Verse 46:15 reads: "We have enjoined man to honor his parents. With much pain his mother bears him, and with much pain she brings him into the world. He is born and weaned in thirty months." According to Islamic thought, the time when an embryo becomes a foetus, i.e. when it receives life (39:6), is around the 120th day of gestation, at which time it may be felt to move in the uterus. After this time no one other than God may pass judgement on it. The remaining 6 months in the uterus and 24 months of breast-feeding thus result in a total period of 30 months during which time maternal rights over the child are established. Breast-feeding is also recommended in verse 2:233: "Mothers shall give suck to their children for two whole years if the father wishes breast-feeding to be completed. They must be maintained and clothed by the child's father." In earlier times the father was obligated to hire a wet nurse to breast-feed the child during this period if the biological mother was unable or unwilling to do so. This created a profound third relationship. Breast-feeding created a "milk-right" between the child and its wet nurse, who became its "milk-mother", and incest prohibitions between the child, its wet nurse and all other children who had been breast-fed by her (the milksiblings) applied (4:23). This tradition has begun to wane in most Muslim communities with the commercial introduction of bottle-feeding.

\section{Fasting is halal}

Muslim fasting involves the total avoidance of all food, drink, smoking and sexual intercourse between sunrise and sunset. Eating is allowed only during the night. The main meals at night consist of the fatoor, the first meal in the evening at which the fast is broken. Tradition has it that the fast is broken by first pronouncing the words "in the name of God the merciful", then drinking a glass of water. Fatoor begins with a piece of bread dipped in salt, followed by a dish of soup, usually made with lentils. It is also tradition to have olives and dates on the table. Sahoor, the second meal, is actually an early breakfast served before dawn, after which the oath to fast during the coming day is taken.

Fasting is recommended in the Koran as a practice of compassion and gratitude (2:182). Ablebodied Muslims are expected to fast throughout the lunar month of Ramadan, the month during which the Koran was first revealed (2:185-86). Individuals who cannot fast for several days during Ramadan for any legitimate reason (travelling, illness, menstruation, etc.) compensate for this by fasting for an equal number of days at some other time. Fasting can also be recommended as compensation for minor misdemeanours such as breaking a promise. Whoever fails to fast without a legitimate reason during Ramadan is expected to feed a certain number of needy people as a penalty (5:89).

\section{Haram rules}

Consumption of certain types of animal flesh and alcohol is prohibited.

\section{Haram meats and meat products}

Several hadith (collections of the Prophet's tradition) prohibit the flesh of "animals with fangs" (carnivorous animals), "animals who live on car- 
rion" (insects) and "creeping animals without ears" (reptiles). No reference is made to these creatures in the Koran, but they are nonetheless avoided as part of the sunna (example of the Prophet). In the Koran a verse in the Surah entitled "The Table" stipulates that "the food of those to whom the Book $\dagger$ was given is lawful for you, and yours for them (5:5)." The reference here is most probably to the food rules in Genesis, 1:29, Leviticus 11:3, 11:7 and 17:12-14. Edible animals in these verses of the Old Testament are those that have cloven hooves and chew their cud. More specific verses of the Koran state: "He has forbidden you carrion, blood and the flesh of swine. You are forbidden the flesh of strangled animals and of those beaten or gored to death; of those killed by a fall or mangled by beasts of prey; also of animals sacrificed to idols (the flesh consecrated to others than God) (2:173, 5:3, 16:114)."

As in Judaism, blood is often alluded to in Islam as signifying the presence of life. It then becomes imperative to discard it before consuming any type of flesh. Rules for halal slaughter are based on the dual principles of effectively draining the animal's blood, without inflicting unnecessary suffering. The requirement for humane treatment is implicit in the prohibition of strangling, striking, piercing or goring animals until they die. In halal slaughter, the jugular vein and the oesophagus are cut with a single stroke of a sharp knife, to interrupt the flow of blood to the brain and thereby render the animal unconscious almost immediately. Animals killed as a sacrifice to pagan gods and other idols are precluded by the requirement that God's name be pronounced at the moment of slaughter. Halal animals are those that are slaughtered only with the intention to consume their flesh, which is implicit in the utterance of the words "in the name of God, the merciful".

The prohibition against pork is sometimes explained by the fact that, although this mammal has cloven hooves, it does not chew its cud. Natural scientific explanations, i.e. that pork was a source of the parasitic infection trichinosis in earlier times, for instance, are also offered. Another explanation for the exclusion of pork involves the difficulty of keeping swine. Because these animals lacked flocking instincts and needed external sources of water to regulate their body temperature, it was not feasible for people to keep them under the social and geographical conditions prevailing in the Middle East during Biblical times.

\section{Wine is haram}

The Prophet has warned in several hadith against foods with psychoactive effects, although the Koran does not contain references to any foods other than wine that may have such effects. Caution in the consumption of wine is prescribed in several verses, and at least three verses warn strongly against wine and encourage total abstention: "Satan seeks to stir up enmity and hatred among you by means of wine and gambling, and to keep you from the remembrance of God and from your prayers. Will you not abstain from them?" (5:90). The existence of these verses coupled with interpretations of the collections of tradition have led to a prohibition of all alcoholic beverages among most Sunni and Shia denominations. Some Sufi groups may have a different interpretation.

\section{Reference}

The Koran with parallel Arabic text. Translated with notes by Dawood NJ. London: Penguin, 2000.

\section{Further reading}

Afifi ZE. Daily practices, study performance and health during the Ramadan fast. J R Soc Health 1997;117: $231-5$.

Al-Naqeeb NA, Azab A, Eliwa MS, Mohammed BY. The introduction of breast milk donation in a Muslim country. J Hum Lact 2000;16:346-50.

Carlson E, Kipps M, Thomson J. Influences on the food habits of some ethnic minorities in the United Kingdom. Hum Nutr Appl Nutr 1984;38:85-98.

Edsman C-M, Hambraeus L, Melander O. Kultur, religion och nutrition. Institutionen för Näringslära, Uppsala Universitet, 1983. (In Swedish.)

Grivett LE, Pangborn RM. Origin of selected Old Testament dietary prohibitions. An evaluative review. J Am Diet Assoc 1974;65:634-8.

Harris M. Cows, pigs, wars and witches. The riddles of culture. New York: Vintage Books. 1974.

Packard DP, McWilliams M. Tips on counseling Middle Eastern clients. J Am Diet Assoc 1994;94:1254.

Sakr AH. Dietary regulations and food habits of Muslims. J Am Diet Assoc 1971;58:123-6.

Sakr AH. Fasting in Islam. J Am Diet Assoc 1975;67:17-21.

Tahire O. Kocturk, PhD, Dr Med Sci

Nutritionist, Family Medicine Stockholm, The International

Centre for Research on Migration, Medicine and Psychiatry,

Alfred Nobels Allé 12, SE-|4I 83 Huddinge, Sweden.

E-mail: tahire.kocturk@klinvet.ki.se 